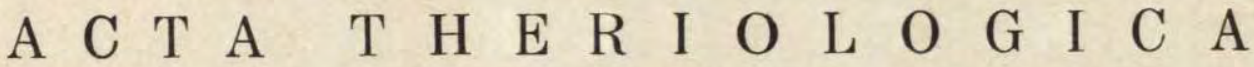

VOL. VI, 2.

BIAEOWIEŻA

10. VII. 1962

\author{
Anna R O M A N K O W O W A
}

\section{Comparative Investigation of the Skeleton of the Hyoid Apparatus in Polish Insectivora and Rodentia}

\section{Badania porównawcze szkieletu aparatu gnykowego u krajowych Insectivora i Rodentia}

\author{
[With 1 table and 22 figs.]
}

I. Introduction

II. Material and methods .

III. Description of the material examined

IV. Comparative review of each element of the skeleton of the hyoid appa-

ratus in Insectivora and Rodentia . . . . . . . . . 25

V. Discussion

VI. Conclusions

References

Streszczenie

\section{INTRODUCTION}

There is no work in Polish literature dealing with the hyoid apparatus of insectivores and rodents occurring in Poland. In world literature $\mathrm{Tu} 1 \mathrm{l} \mathrm{be} \mathrm{rg}$ (1899) was the first to draw attention to the taxonomic importance of the hyoid apparatus in rodents, while the first description of this apparatus in Insectivora (Talpa, Erinaceus) is given by Cuvier (1835). S prague $(1941 ; 1942 ; 1943 ; 1944)$ gives an sccurate history of research on the hyoid apparatus in mammals and a comprehensive list of references on the subject. This author investigated the hyoid apparatus in several species of Cricetinae belonging to the following genera: Onychomys, Reithrodontomys, Peromyscus, Oryzomys, Sigmodon, Neotoma, Hodomys, Xenomys, and in the case of insectivores - chiefly Echinosorex, Erinaceus, Tupaia. Amongst more recent works on this problem mention must be made of the work by $\mathrm{S}$ a $\mathrm{ugh} \mathrm{r}$ a $\mathrm{n}$ (1954) on the osteology and myology of the cranial and cervical regions of Blarina and Scalopus. 
In the present work the different elements of the hyoid apparatus have been marked according to the nomenclature used by Sprag u e (1941).

The aim of the work was to obtain a knowledge of the structure of the skeleton, and to compare the component elements of the hyoid apparatus in different systematic units of the orders of mammals investigated.

I should like to express my grateful thanks to Professor Dr. Wacław Sk u r a towi c z for the help he so willingly gave me during the preparation of this work.

Table 1.

A list of the investigated species.

\begin{tabular}{|c|c|c|}
\hline Order & S p e c i e s & $\begin{array}{c}\text { Number } \\
\text { of } \\
\text { specimens }\end{array}$ \\
\hline Insectivora & 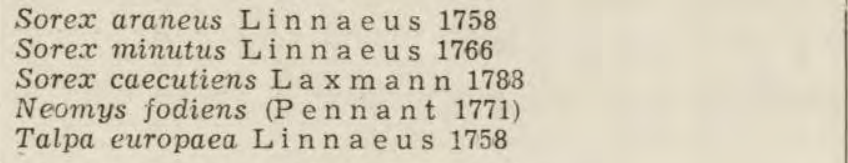 & $\begin{array}{l}4 \\
2 \\
1 \\
2 \\
5\end{array}$ \\
\hline Rodentia & 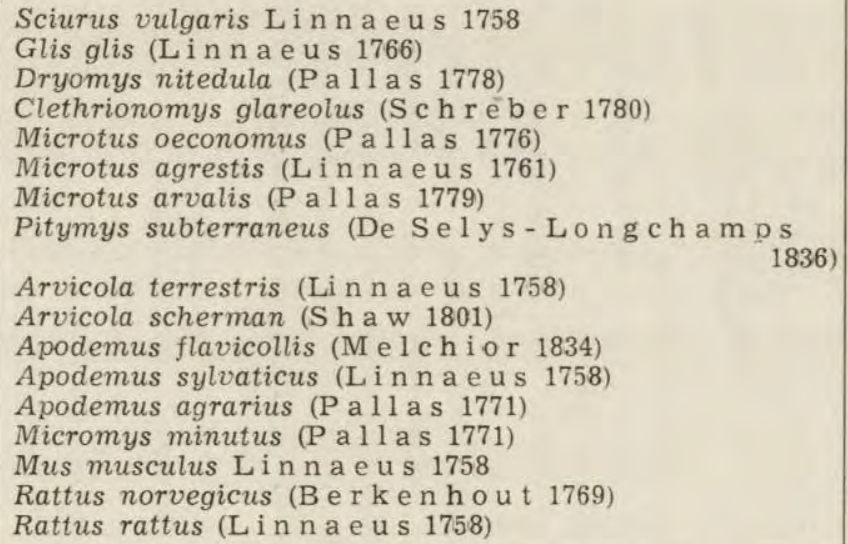 & $\begin{array}{r}1 \\
3 \\
1 \\
4 \\
2 \\
1 \\
1 \\
1 \\
2 \\
2 \\
6 \\
6 \\
1 \\
2 \\
7 \\
6 \\
2 \\
6 \\
2 \\
1\end{array}$ \\
\hline
\end{tabular}

\section{MATERIAL AND METHODS}

Part of the material (Sorex caecutiens, Sorex minutus, Apodemus flavicollis, Microtus oeconomus) came from the collection in the Mammals Research Institute of the Polish Academy of Sciences, while the remainder was presented to me by Professor Dr. Waclaw Skuratowicz. I am most grateful for the material put at my disposal for use in my investigations.

The species examined have been set out in table 1. A total of 76 individuals were examined. The method chiefly used in my investigations was examination of preparations under a dissecting microscope, supplemented by clearing the muscles by M a 1l's method and staining the bones with alizarine. 


\section{DESCRIPTION OF THE MATERIAL EXAMINED}

The names of the bones given in fig. 3 refer to Insectivora, and in fig. 20 to Microtidae and Muridae examined.

$$
\text { Sorex araneus Linna e us } 1758 \text { - Fig. } 1 .
$$

The basihyal is a smooth-sided trabecula, elongated, slightly arched in the cranial direction. The terminal ends of the bone are slightly thicker, with wide articular surfaces. The basihyal is articulated on the caudal side with the thyrohyal, and on the latero-cranial side with the hypohyal. The thyrohyal is long, trabecular, runs from the basihyal in a medio-cranial direction. The free end is extended by a flat, relatively short cartilaginous element. On the proximal end of the bone there is a broad cranial articular surface with the basihyal. The proximal end of the hypohyal has an articular surface with the basihyal, and a distal one with the ceratohyal. Both surfaces are relatively large and round. The shaft of the bone is flattened into a taeniform shape, twisted in the long axis; the distal end is curved in the form of an arch in the dorsomedial direction. The ceratohyal is slender, phalangeal, with thickened, rounded basal parts, is set dorso-laterally, forming a slightly obtuse angle with the typohyal. The stylohyal is slender, phalangeal, with slightly thickened and rounded basal parts. In relation to the ceratohyal it is situated at a slightly obtuse angle, inclined laterocaudally. There are cartilaginous rod at both ends of this bone. The cartilage lying proximally is relatively short, situated on the dorsal side of the ceratohyal, its free end protruding slightly beyond this element in the cranial direction. The cartilage running as an extension of the distal end of the stylohyal in the latero-caudal direction is long and fixed to the cranium.

$$
\text { Sorex minutus Linnaeus } 1766 \text { - Fig. } 2 .
$$

The basihyal is a slender smooth-sided trabecular with thickened and rounded ends. This bone is slightly arched, the convex side facing the cranial direction. There are large articular suriaces at the ends of the bone - the latero-cranial with the hypohyal, and the caudo-lateral with the thyrohyal. The thyrohyal is a slightly arched bony trabecula, the convex part turned in the ventral direction. At the terminal end of the bone there is a short, cone-shaped cartilaginous element protruding on to the dorsal side of the hyoid apparatus. The hypohyal is thicker in the proximal region, set cranially in relation to the basihyal, the distal region of the bone is thinner, directed latero-cranially. The proximal articular surface is situated vertically to the long axis of the bone, the terminal end is bevelled. The ceratohyal is phalangeal, slightly longer 
than the element described above, slightly arched, - the convex side directed cranio-dorsally. The stylohyal is slender, phalangeal very elongated, set at an obtuse angle in relation to the ceratohyal. The proximal region of the bone is slightly thicker than the distal region. The articular surface with the ceratohyal is situated on the ventral surface of the proximal end of the bone, terminated by a short cone-shaped cartilaginous element; on the distal end of the stylohyal there is an elongated, cartilaginous rod set at an obtuse angle in relation to the stylohyal.

$$
\text { Sorex caecutiens La x m a n n } 1788 \text { - Fig. } 3 .
$$

The basihyal is an elongated bony trabecula flattened cranio-caudally, set transversely to the long axis of the body. The ventral edge of the bone is raised slightly in the cranial direction. The terminal ends of the bone are thickened, and on them are the relatively large articular surfaces: the latero-cranial with the hypohyal, and the latero-caudal with the thyrohyal. The thyrohyal is phalangeal, almost the thickness of the basihyal, and forms a half-arch, the convex side of which is directed ventrally. At the end of the thyrohyal there is a cartilaginous element passing in the form of an arch to the dorsal side of the hyoid apparatus. The hypohyal is twice as thick in the proximal region, which is set craniolaterally in relation to the basihyal; midway along the bone is bent at an angle of almost $45^{\circ}$ in the latero-dorsal direction. The proximal articular surface of the bone is situated vertically to the long axis of the bone, the terminal end of which is cone-shaped. The ceratohyal is phalangeal, the proximal part of the bone is slightly thicker, rounded, the articular surface being bevelled. On the flat distal end there is a cone-shaped cartilaginous base. The stylohyal is elongated, with slightly thicker bases. On the ventral surface of the proximal end of this bone there is an articular surface with the ceratohyal, with which this bone forms a right angle. At the proximal end of the element examined there is a cartilaginous, cap-shaped element, protruding in the cranial direction beyond the limits of the hyoid apparatus. At the terminal end of the bone there is a rod-shaped elongated cartilage bent slightly in the lateral direction in relation to the stylohyal.

$$
\text { Neomys fodiens (P ennant 1771) - Fig. } 4 .
$$

The basihyal is a smooth-sided bony cylinder, the medial region of the bone being raised slightly in the cranial direction. The terminal ends are thickened and clavate, with the following articular surfaces formed on them: the cranial with hypohyal, and the ventro-caudal with thyrohyal. The thyrohyal is shaped like a boomerang, with the convex 
part directed ventrally. On the terminal end of the bone there is an elongated, cartilaginous element. The hypohyal is a relatively thick trabecula, bent in a bow-shape, the convex side being directed ventrally. The proximal end of the bone is set craniolaterally in relation to the basihyal, the distal - latero-dorsally. The ceratohyal is slender, phalangeal, situated latero-dorsally in the extension of the hypohyal. The stylohyal is the element which is situated most dorsally of the hyoid apparatus, runs in a caudal direction from the ceratohyal, forming a right angle with it. This bone is shaped like an elongated slender phalange. The articular surface with the ceratohyal is situated on the ventral surface of the bone, shifted slightly towards the centre of the bone. On the proximal end of the bone there is a short, sharply-ended cartilaginous element, while on the distal end the element is elongated and rod-shaped.

Talpa europaea Linn a us 1758 - Fig. 5.

The basihyal is a bony trabecula flattened craniocaudally. On the cranial surface of the bone there are two prominences on the terminal ends, joined medially with each other. In the region of these nodules there are relatively large articular surfaces with the hypohyals. The ends of the bone are bent caudally - situated on them are the articular surfaces with the thyrohyals. The caudal surface of the bone is concave, forming a shallow hollow. The thyrohyal is situated caudo-laterally in relation to the basihyal, is elongated, bilaterally ilattened, twisted in the long axis. The pre-axis edge of the bone is straight, the post-axis strongly bulging and rounded in the terminal region. On the terminal end of the bone there is a cone-shaped cartilaginous element. The hypohyal is an elongated, broad and flattened element, situated cranio-laterally to the basihyal. The ends of the bone are bent in a lateral direction. The proximal end of the bone is slightly thicker, set more ventrally than the distal end. The ceratohyal is the length of the hypohyal, set dorso-caudally in relation to it. It is a bone of slender structure, with ends slightly bent in the lateral direction. The stylohyal is even more slender than the ceratohyal, almost twice as long the ends of the bone are slightly thicker. This element is situated caudally in relation to the ceratohyal, dorsally in relation to the basihyal. The proximal end of the bone is bent slightly in the ventral direction, and the distal end - in the dorsal direction. On the distal end of the bone there is a flat, elongated cartilaginous element.

$$
\text { Sciurus vulgaris Linn a us } 1758 \text { - Fig. } 6 .
$$

The hyoid apparatus in the species examined consists of a non-paired bone, set centrally, and two segmented anterior cornua. The lack of earlier stages of development in material investigated makes it impossible 

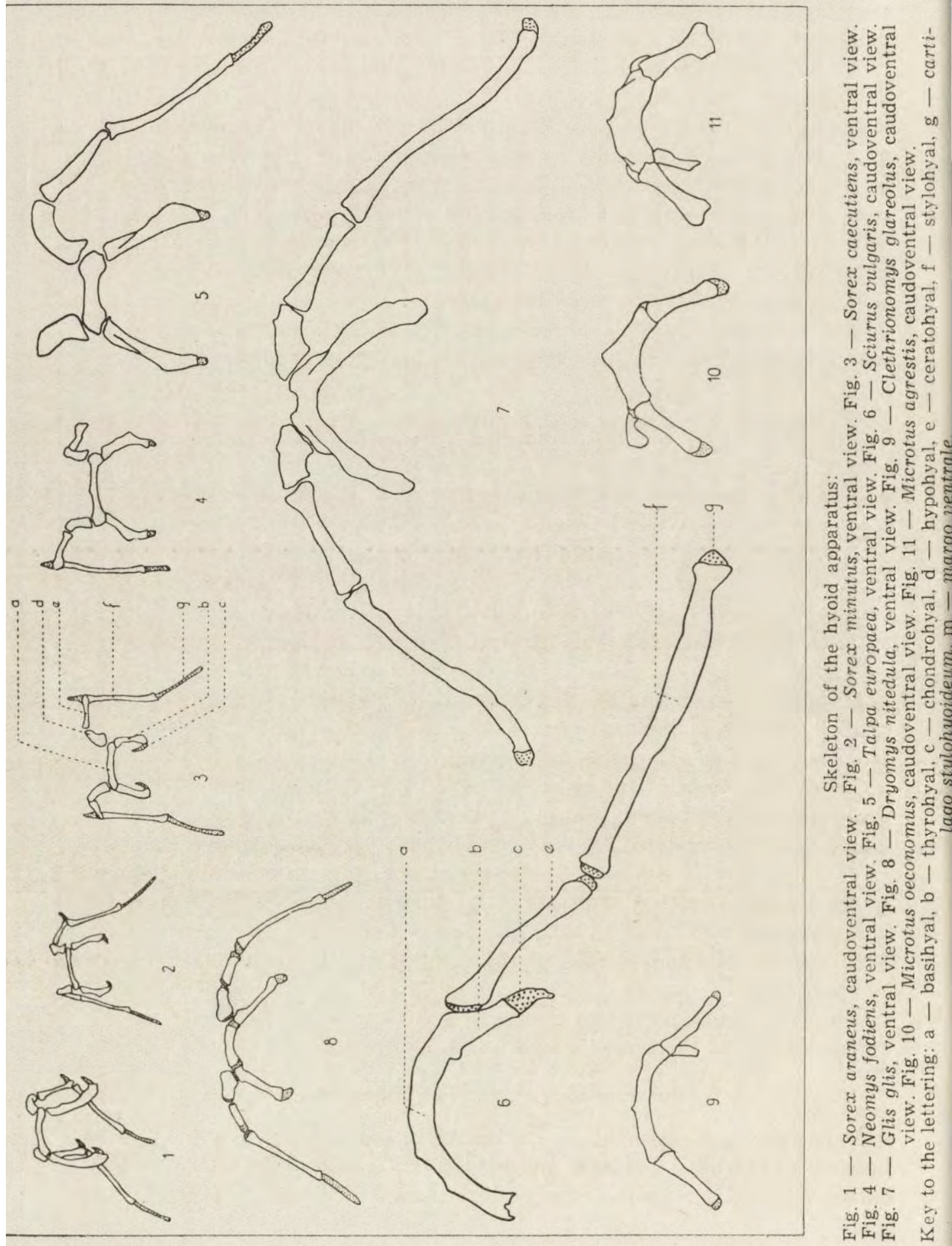


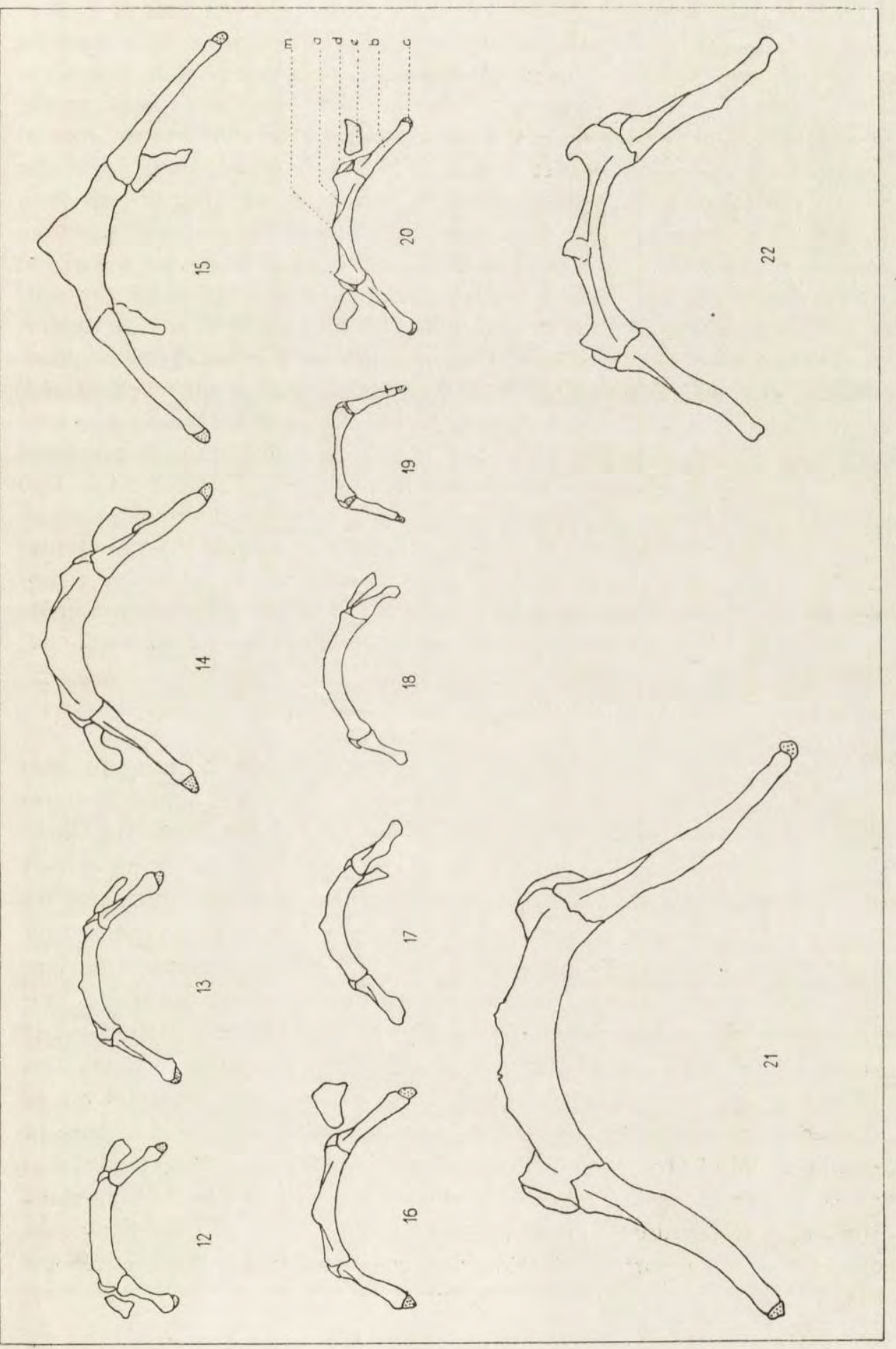

ำ

․․ㄹ

.

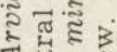

1 3

t

की

का

훙요 즁

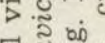

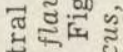

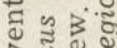

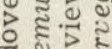

รีำ

0 월

范1

है 0

단

จั

के

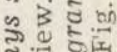

हो $>$

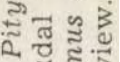

1 \%ึ.

m

हुँ हू

की है।

4.

उद

>잉ำ

ส․ำ

步市号

०।

ㄱำ

을

कीज है।

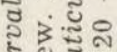

t.

उ जै

牙 क

है है है

วิ

1 훙

거

का

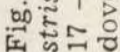


to state if the centrally situated bone is a non-paired element, or a complex one. It is sturdy, flattened dorsoventrally, curved in the shape of a horse-shoe. The medial part of the dorsal edge is smooth, there are large, narrow articular surfaces connecting with the ceratohyal on the terminal ends of this edge. On the ventral edge of the bone in the medial region there are two nodules fusing with each other, inclined in the cranial direction. The terminal ends of the bone are slightly twisted, bordered with cartilaginous, flattened bases. The ceratohyal is phalangeal, slender, slightly bent in a arch - the ends of the bone turned in the cranial direction. The bone is set latero-caudally in relation to the basihyal. The proximal region of the bone is slightly thicker, the medio-caudal articular surface connecting with the central bone is elongated, situated obliquely in relation to the long axis of the element examined. The terminal end of the bone is also thickened, massive, ending in a cartilaginous discoid element. There is a similar element on the proximal end of the stylohyal. There is an articular interstice between the two discs. The stylohyal is set even more laterally than the previous element, is elongated, bow-shaped, the terminal ends are turned in the cranial direction. The proximal part of the shaft is narrow, with round cross-section, while the bone becomes flattened and slightly broadened in its continuation. There is a short, flat, rounded element on the terminal end.

$$
\text { Glis glis (Linna e us 1766) - Fig. } 7 .
$$

The basihyal is a trabecula flattened dorso-ventrally, forming an arch convex in the direction of the ventral plane. At the ends of the basihyal there are articular surfaces with the thyrohyal, with which the bone forms a closed arch. In the distal parts of the bone there are cranio-dorsal articular surfaces with the hypohyals. The thyrohyals are thickened on the proximal ends, and are connected with the basihyal and hypohyal by joints. The distal ends of the bone are flattened cranio-caudally, both terminal ends of this element are raised in the dorso-cranial plane. The hypohyal is flattened dorso-ventrally. The basihyal region of the bone is broader. The cranial edge is arched convexly, the caudal is concave. The ceratohyal has both ends flattened dorso-ventrally. The stylohyal is flattened dorso-ventrally, twisted in the long axis, the proximal base is set at an angle of about $45^{\circ}$ in relation to the distal base. The right stylohyal is like an elongated letter $\mathrm{S}$ in shape, the leit is its looking-glass reflection. The terminal ends of this bone are rounded. All the bony elements forming the cornu anterrior are connected with each other by means of joints. 
Dryomys nitedula (P a 11 as 1778) - Fig. 8.

The basihyal is relatively short, trabecular, with slightly broadened end parts. They are situated transversely to the long axis of the body. On the terminal ends of the bone there are the lateral articular surfaces which articulate with the thyrohyal, and latero-cranially articulate with the hypohyal. The thyrohyal as a thick, many-sided proximal basal part, forming the horizontal extension of the basihyal. The medio-cranial surface of this bone articulates with the basihyal, and the cranio-lateral with the hypohyal. The shaft of the bone is phalangeal, slightly twisted in the long axis. The further basal part is slightly broadened, rounded. This bone is situated latero-caudally in relation to the basihyal, and together with it forms the shape of an arch. The hypohyal is phalangeal, elongated, set at an angle of $45^{\circ}$ in relation to the basihyal, from which it runs in the dorso-lateral direction. The proximal end of the bone is thickened, rounded, the caudal articular surface which connects with the basihyal is relatively large, bevelled, the distal end of the bone is slightly broadened and clavate. The ceratohyal is slightly shorter than the hypohyal, phalangeal, the end parts are slightly broadened and clavate. The bone is set parallel to the basihyal. The stylohyal is elongated, about twice as long as the thyrohyal, dorso-ventraly flattened, narrowing evenly from the broad proximal end towards the terminal end. This bone reaches to the height of about one-half the length of the bulla tympanica, not directly connecting with the skull.

Clethrionomys glareolus (S ch r e ber 1780) - Fig. 9 .

The basihyal is a slender bony trabecula, flattened cranio-caudally, situated transversely to the long axis of the body. The terminal ends of the bone are thickened, and on them lie the articular surfaces - the lateral with the hypohyal, the latero-caudal with the thyrohyal. The triangular, spinelike proc. lingualis is situated on the ventral edge of the bone. The thyrohyal is set latero-caudally in relation to the basihyal, flattened dorso-ventrally. This bone gradually becomes increasingly slender from the thicker proximal region to the thin terminal end, which finishes in a cone-shaped cartilaginous element. The distal region of the bone is bent laterally. The hypohyal is a relatively small element connecting by synarthrosis with the basihyal and thyrohyal. The articular surface with the ceratohyal is on the lateral surface of the bone. The ceratohyal is a short, bony trabecula with ends bent in the cranial direction, situated latero-cranially in relation to the basihyal. The basihyal, thyrohyal and hypohyal, as they develop individually, coalesce with each other comparatively early, forming a single bony process. 


$$
\text { Microtus oeconomus (P a } 11 \text { as 1776) - Fig. } 10 .
$$

The basihyal is a broad plate flattened craniocaudally. The ventral edge of the bone is arched triangularly, slightly folded on the cranial side. The ends of the bone are thickened from the caudal and cranial side, and connect by synarthrosis with the thyrohyal and hypohyal. The hypohyal is relatively small, situated dorso-laterally, shallowly built in between the basihyal and thyrohyal. The thyrohyal is relatively long, phalangeal. The proximal end of the bone is massive, the central part slender, elongated, the terminal end is dorso-ventrally flattened, slightly broader, rounded. The ceratohyal is dropshaped, flattened at the wider terminal end. It is situated dorso-laterally in relation to the remaining elements of the hyoid apparatus.

$$
\text { Microtus agrestis (Linnaeus 1761) - Fig. } 11 .
$$

The basihyal is a broad, cranio-caudally flattened plate, slightly bent in the form of a bow. The ventral edge of the bone is slightly raised in the cranial direction. On the terminal ends of the cranial surface there are two thickenings. The ends of the plate connect by synarthrosis with the hypohyal and thyrohyal. The thyrohyal in the proximal region in thickened, massive, the medial region is slender, the distal region wide and flat. The bone is set latero-caudally in relation to the basihyal. The hypohyal is relatively large and occupies the space between the basihyal and thyrohyal, coalescing with them by synarthrosis. On the dorsal surface of the bone there is the articular surface with the ceratohyal, set laterodorsally. The ceratohyal is oval, ilattened, the proximal end of the bone is massive.

$$
\text { Microtus arvalis (P a } 11 \text { as 1779) - Fig. } 12 .
$$

The basihyal is a bony trabecula flattened cranio-caudally. The caudal surface of the central part is slightly concave, convex in the cranial direction. The cranial edge of the bone forms an approximately straight line, is set transversely to the long axis of the body. The terminal ends of the bone are thickened from the caudal side, the shape of the caudal edge of the bone forms a bow. The ventral edge of the bone is flattened, lightly bent in the cranial direction, the free border of this edge is either irregularly ragged or has a small spine-like process set medially. The basihyal articulates with the thyrohyal and hypohyal. The thyrohyale is set latero-caudally in relation to the basihyal, is the shape of a phalanx with narrowed medial region and thicker ends. The proximal end of the bone is massive, the terminal end slightly broader, rounded, strongly flattened dorso-ventrally. In adults the basihyal, thyrohyal and hypohyal 
are strongly coalesced with each other, forming a single bone. The hypohyal is small, fills the gap between the basihyal and thyrohyal. The ceratohyal is set cranio-laterally in relation to the basihyal, is drop-shaped with a narrow end set proximally. The bone is strongly flattened, curved in the long axis about half shorter than the thyrohyal.

$$
\text { Pitymys subterraneus (De Sely s Long champs 1836) - Fig. } 13 .
$$

The basihyal is an elongated, slender bony trabecula flattened cranio-caudally, with thickened terminal ends. The caudal edge of the bone forms a sectional arch, the ventral edge is slightly raised in the cranial direction. The thyrohyal is relatively short, phalangeal, situated latero-caudally in relation to the basihyal. This bone is flattened and twisted in the long axis. The hypohyal is relatively short, connected by synarthrosis with the basihyal and thyrohyal, filling the gap between both these bones on the side of the latero-cranial surface. This bone is connected by a mobile joint with the ceratohyal. The ceratohyal is set latero-dorsally in relation to the bones described previously, and is the shape of a flattened drop.

$$
\text { Arvicola terrestris (Linna e us 1758) - Fig. } 14 .
$$

The basihyal is a wide plate flattened cranio-caudally. The ventral edge of the bone is usually slightly arched and undulating. The medial region of the edge is formed like a flattened, broad nodule. In one of the individuals examined there was a processus lingualis. The dorsal edge of the bone is slightly concave. The thyrohyal is flattened dorso-ventrally, on the terminal end of the bone there is a cartilaginous, flat, triangular base. In the individuals examined the basihyal, thyrohyal (and probably the hypohyal) form a single bony element, with strongly fused sutures. The ceratohyals are set on the dorso-caudal edge of the shaft. These are elongated flat small bones of irregular shape, the proximal end of which is narrower, the terminal broader, with a blunt end.

Arvicola scherman (S h a w 1801) - Fig. 15.

The basihyal is a wide plate flattened craniocaudally. The ventral edge of the bone is formed by two steeply rising sides enclosing a triangular space. The caudal edge is slightly concave. The hypohyal is very small, and is set on the dorso-lateral surface of the hyoid apparatus between the basihyal and thyrohyal. The thyrohyal is elongated, the proximal region of the bone is massive, the medial and terminal regions slender. At the end of the bone there is an elongated cartilaginous element. The ceratohyal is massive in the proximal region, flattened in the terminal region. 
The lateral edge is straight, the medial has a bow-shaped incision. The articular suriace on the proximal end of the bone is bevelled, the terminal edge is set at a right angle to the dorsal and ventral edges.

$$
\text { Apodemus flavicollis (M e l chior 1834) - Fig. } 16 \text {. }
$$

The basihyal is a relatively thick trabecula cranio-caudally flattened. The ventral edge of the bone is convex, bow-shaped, slightly folded in the cranial direction. The cranial surface of the bone is slightly concave. The terminal ends of the bone are thickened, and on them are the surfaces of the synarthroses with the thyrohyal and hypohyal. The thyrohyal is relatively long, phalangeal, twisted in the long axis. The proximal basal part is massive, the medial region slender, the terminal region on the bone slightly broadened and flat. At the terminal end of this element there is a short cartilaginous, flattened element. The medial edge of the thyrohyal is bent in a bow-shape. The hypohyal fills the gap between the basihyal and thyrohyal from the side of the latero-dorsal surface. The medial surface of the bone contacts with the basihyal, the caudo-lateral with the thyrohyal, the surface which is not built-in is convex, curved in the form of a bow. In the region of the hypohyal there is the characteristic "shoulders" of the sides of the hyoid apparatus. The ceratohyal is flat, bean-shaped, the proximal end of the bone is only half as wide as the distal.

$$
\text { Apodemus sylvaticus (Linnaeus 1758) - Fig. } 17 .
$$

The basihyal is a bony trabecula, flattened cranio-caudally in the medial region. The terminal ends of the bone are thickened and are connected by synarthrosis with the laterocaudal surface and the thyrohyal, and the lateral with the hypohyal. The caudal edge of the bone is bent in a bow-shape. The ventral edge of the bone is raised in an arch with irregular formation of the marginal line. This part of the bone is flattened, slightly folded in the cranial direction. The thyrohyal is elongated, with slightly thicker proximal region. The terminal ends of the bone are directed laterally. The hypohyal is relatively small, fills the gap between the basihyal and thyrohyal from the latero-dorsal side, and is inserted between these two bones. The ceratohyal is set dorso-caudally in relation to the hyoid arch. It is a flat plate with slightly thicker proximal end, on which is the articular surface with the hypohyal. The terminal end of the bone is rounded.

$$
\text { Apodemus agrarius (P a } 11 \text { as 1771) - Fig. } 18 .
$$

The basihyal is a trabecula, flattened cranio-caudally, strongly bent in the form of a bow. The region of the ventral edge of the bone is flattened, 
the ventral edge is slightly arched, very slightly folded in the cranial direction, the free edge is irregularly undulating, there is a relatively short process in the medial part. The thyrohyal is relatively short, flattened. The proximal end of the bone is connected with synarthroses by means of the medio-caudal surface with the basihyal and hypohyal. The distal end of the bone is widened and rounded. The hypohyal is a sturdy little bone filling the gap between basihyal and thyrohyal. The free latero-cranial surface of the bone is strongly convex. The basihyal, thyrohyal and hypohyal are connected with each other by synarthroses, forming a bony element similar to a bow in shape. The ceratohyal is relatively long, slightly twisted in the long axis, flattened. On the side of the articular surface with the hyoid bow this bone is slightly narrower, is rounded and broadened at the distal end. The ceratohyal is connected by a diarthrosis with the hyoid bow, and is situated medio-caudally.

$$
\text { Micromys minutus (P a } 11 \text { as 1771) - Fig. } 19 .
$$

The basihyal is elongated, set transversely to the long axis of the body. The medial region of the bone is strongly flattened cranio-caudally, the end part is considerably thickened from the caudal side, slightly less from the cranial side. The outline of the cranial edge of the bone is slightly concave, that of the caudal edge strongly concave. On the ventral edge of the bone there is a low, flattened cone with a broad base. The terminal ends of the bone are connected by synarthroses with the thyrohyal and hypohyal, and by diarthrosis with the ceratohyal. The thyrohyal is set caudo-laterally in relation to the basihyal. This is a phalangeal bone, twisted in the long axis. The terminal end of the bone is turned slightly medially. The hypohyal is inserted like a wedge between the basihyal and thyrohyal from the side of the lateral surface. The free surface of the bone is relatively flat. The distal ends of the basihyal, the proximal ends of the thyrohyal and the hypohyal form "shoulders" on the sides of the hyoid apparatus. The ceratohyal varies in shape. In general the proximal part is thicker and massive, the distal region is flattened.

$$
\text { Mus musculus Linnaeus } 1758 \text { - Fig. } 20 .
$$

The basihyal is elongated, situated transversely to the long axis of the body. The medial region of the bone on the cranial surface is slightly raised, the distal ends are thickened. The caudal surface of the basihyal is arched. The ventral edge of the bone is flat, strongly folded in the cranial direction. The thyrohyal is set latero-caudally in relation to the basihyal. It is an elongated, flattened element, slightly twisted in the long axis, the terminal end of the bone is laterally bent. The proximal region of the bone is massive, slightly thicker than the rounded distal 
region. The medial region is slightly narrower. The hypohyal is built into the space between basihyal and thyrohyal from the side of the lateral surface, shallowly inserted betwen both these bones. The basihyal, thyrohyal and hypohyal at the place of contact form strong lateral arches of the hyoid apparatus, the "shoulder" on the sides. The ceratohyal is relatively small in the individuals examined. It is a plate in the form of a flattened drop, on the narrower proximal end there is an articular surface.

$$
\text { Rattus norvegicus (B e rken hout 1769) - Fig. } 21 .
$$

The hyoid apparatus in this species is massive and large. The basihyal is set transversely to the long axis of the body, slightly arched. It is a massive trabecula, flattened craniocaudally. The cranial surface of the bone is flat, the caudal concave, owing to the thickening of the terminal ends. The dorsal edge of the bone is smooth, the ventral edge is arched, irregular, ragged, folded slightly on the cranial side. The hyoid bone is connected by synarthrosis from the caudal side with the thyrohyal, from the lateral with the hypohyal. The thyrohyal is elongated, flattened bilaterally, twisted in the long axis. The basihyal region of the bone is slightly thicker, massive, the bone becoming more slender towards the terminal end. The terminal end is bent laterally, and on it there is a short, cartilaginous element. The hypohyal is relatively large, and fills the gap between the basihyal and thyrohyal. The free surface of the bone is arched convexly, and overlaps the cranial edge of the basihyal. The terminal end of the basihyal, the proximal end of the thyrohyal and the hypohyal form strong lateral "shoulders" on the sides of the hyoid apparatus. The ceratohyal is relatively small and massive.

$$
\text { Rattus rattus (Linnaeus 1758) - Fig. } 22 .
$$

The basihyal is strongly flattened cranio-caudally in the medial region, the terminal ends of the bone are thickened. The cranial edge of the bone seen from the side of the ventral survace is depressed in the form of a shallow basin, the caudal edge is convex and forms half of a bow-shape. On the ventral edge, which is slightly convex, there is a low nodal process in the medial part, slightly arched in the cranial direction. The thyrohyal is massive in the proximal part, flattened on both sides, growing thinner towards the terminal end, and twisted in the long axis. The terminal end is inclined latero-dorsally, ending in a short cartilaginous element. The hypohyal is wide, situated latero-dorsally, inserted shallowly between basihyal and thyrohyal, overlaps on to the cranial edge of the basihyal The ceratohyal is relatively large, flattened, the proximal end of the bone 
is narrower, the bone seen from the side is similar to a wide, flattened drop in shape. The ceratohyal is set latero-dorsally in relation to the hypohyal, with which it is connected by means of a diarthrosis.

\section{COMPARATIVE REVIEW OF DIFFERENT ELEMENTS OF THE SKELETON OF THE HYOID APPARATUS IN INSECTIVORA AND RODENTIA.}

The basihyal is elongated, set transversely to the long axis of the body. It is slender and phalangeal in Soricidae, flattened cranio-caudally in Sorex caecutiens and Neomys fodiens; it has the shape of a short trabecula, with basin-like depression from the caudal side, in Talpa; a short bow-shaped trabecula in Muscardinidae; a long plate bent in a bow-shape, flattened dorso-ventrally in Microtidae and Muridae. The bow-shaped arch of the basihyal points in the cranial direction, with the exception of Muscardinidae, in which it is directed ventrally. The ventral edge of the bone in Insectivora, Muscardinidae and Sciurus is usually smooth, in Microtidae and Muridae varies in shape. In Clethrionomys glareolus there is a relatively low, triangular process, set medially, on both sides of which there is a symmetrical concavity. In Microtus arvalis, Pitymys subterraneus, Microtus agrestis, and in part of the specimens of Arvicola terrestris, this edge has the outline of a sectional bow. most strongly convex with Microtus agrestis. Of the Muridae examined, a similar structure of the edge is found in Apodemus sp., Mus musculus, Rattus norvegicus. In the majority of the Microtidae examined there are several asymmetrical prominences on the marginal line of the edge. Among Muridae, in Rattus norvegicus the marginal line has several peaks, is ragged, in Apodemus agrarius and Apodemus sylvaticus two asymmetrical prominences occur in Mus musculus one - strongly folded in the cranial direction. The ventral edge in Arvicola scherman and Microtus oeconomus is convex in the form of a triangle, with extremely steep sides in the first of the species mentioned. In Micromys minutus and Rattus rattus, the ventral edge is shaped like a triangle with an extremely obtuse apical angle. The proc. lingualis seldom if ever occurs in the animals examined. Only in Clethrionomys glareolus, Rattus rattus and certain specimens of Arvicola terrestris examined is there a nodal process in the medial region of the ventral edge. In all the rodents examined the ends of the basihyal are bent in the caudal direction.

The thyrohyal is elongated in all the species examined. In certain Muridae, Cricetidae and Talpa it is twisted in the long axis. The proximal region of the bone is always thicker. In Sorex sp. and Dryomys this bone is phalangeal, in Neomys shaped like a boomerang, in Talpa and Glis it is flattened on both sides. In Arvicola sp., Clethrionomys, Micromys and 
in Sciurus this bone is clavate, growing more slender towards the terminal end. In Microtus sp., Apodemus sp., and Mus the terminal region of the bone is to a greater or lesser degree broadened, flattened and rounded. With the Insectivora and Muscardinidae examined this bone is connected by diarthrosis with the basihyal, in the remaining rodents during individual development coalescence of these two bones (synarthrosis) occurs fairly early. On the terminal end of the bone there is a cartilaginous element; cap-shaped and short in rodents and part of the insectivores, elongated and curved in a bow-shape in Sorex sp.

The hypohyal is small, built-in between basihyal and thyrohyal in Muridae and Cricetidae, ossifying in individual development later than the two bones mentioned. It does not constitute an independent mobile unit. It would seem that this bone does not occur in Sciurus. In Insectivora and Muscardinidae the hypohyal forms the shortest unit, independent and proximally situated, of cornu anterior. In these animals it is sturdy, with a thicker proximal end, which by diarthrosis is connected with the basihyal, the distal region of the bone inclines in an arch in the latero-dorsal direction. The distal end of the bone is connected by the diarthrosis with the ceratohyal.

The ceratohyal in the Muridae and Microtidae examined is a relatively small bony element, with variable shape, even in different individuals belonging to the same species. Most often it is shaped like a flattened drop. The proximal end of the bone is connected by a diarthrosis with the shaft of the hyoid apparatus at the place whether the hypohyal is situated. The terminal end of the bone is built into the muscle running to palatum molle. With Insectivora and Muscardinidae this element is phalangeal, slightly longer than the hypohyal, connected with it and with the stylohyal by means of diarthrosis. In Sciurus this element is connected with the basihyal on one side and with the stylohyal on the other.

The stylohyal is the longest element of the three component bones of cornu anterior. It does not occur in the Muridae and Microtidae examined. In Glis it is similar in shape to an elongated letter S, in the remaining species examined it is shaped like a phalanx.

Cartilago stylohyoideum is an elongated cartilaginous rod in all the Insectivora. In Sciurus and Glis, it is short and cap-shaped.

\section{DISCUSSION}

Differences in the structure of the skeleton of the hyoid apparatus in the different groups of animals examined are evident in the material investigated. A slightly different structure of the hyoid apparatus is 
possessed by insectivores, and a different one by rodents. Of the insectivores examined, the massive hyoid apparatus of Talpa is clearly defined, maintaining the number of component units and the general features of structure in common with Soricidae. In the rodents examined the types of structure are in general grouped within the families. Only Muridae and Microtidae exhibit a relatively great similarity of structure. In both these families the hypohyal is irserted between the basihyal and thyrohyal, not occurring anywhere as an independent mobile element of the cornu anterior. The ceratohyal in these animals is a rather small broad bone. In the species which I examined there is no direct connection between the hyoid apparatus and skull. S p r a g u e (194.1) in his examinations of the hyoid apparatus of Cricetidae of North America found such relation in Oryzomys, Sigmodon and Hodomys.

Despite the individual variation occurring it is possible to distinguish a group of certain features of structure characteristic of the different species.

The difference between the description of the structure of the hyoid bone in the rat, given by $\mathrm{G} \mathrm{a} \mathrm{m} \mathrm{bary} \mathrm{a} \mathrm{n} \mathrm{\&} \mathrm{D} \mathrm{u} \mathrm{kels} \mathrm{k} \mathrm{a} \mathrm{y} \mathrm{a} \mathrm{(1955)} \mathrm{and}$ my own observations gives grounds for reflection. In the species I examined, Rattus rattus and Rattus norvegicus, I did not find the occurrence of any direct skeletal connection between the hyoid apparatus and skull. The authors mentioned above give in their monograph, Chapter I, three species of Rattus with the subspecies occurring in the Soviet Union, but it is impossible to discover from the text which species is referred to from the anatomical description. An explanation of this case might be interesting from the aspect of comparative anatomy.

Variations in structure formed a basis for investigating the correlation between formation of the hyoid apparatus and the systematic appurtenance of individuals. T u $1 \mathrm{lb}$ b $\mathrm{g}$ (1899) in rodents, S prag u e in Cricetidae (1941), C h i ropter a (1943), Insectivora (1944), found variations in structure of the hyoid apparatus depending on the systematic appurtenance of the individual.

O w e $\mathrm{n}$ (1835) indicates the dependence existing between the structure of the hyoid apparatus and the sound uttered by Felidae. P o ckock (1917) distinguished two of the three subfamilies of Felidae on the basis of the structure of the hyoid apparatus. Comparative examinations of the larynx and hyoid apparatus in bats ( $\mathrm{E} 1 \mathrm{i}$ a s, 1907-1908) preceded the discovery of the supersonic orientation in these mammals (P i e r c e \& $\mathrm{Gr}$ iffin, 1938). It was found that certain Soricidae, Muscardinidae, Muridae (K a h m a n \& Os t e r m a n, 1951), Clethrionomys (S c h l eid t, 1948) utter supersounds with a frequency of about $30 \mathrm{KHz}$.

The connection between structure of the hyoid apparatus, and the way 
in which they feed, was observed by Do bs on (1881) in Epomops franqueti.

It would seem that both the way in which sounds are uttered and the way of feeding and swallowing food are factors modelling the shape, size and massiveness of structure.

An important problem from the aspect of comparative anatomy is the question of the homology of different bony elements. It would seem that the basihyal and thyrohyal are homological in all the families examined. The homology of the remaining elements coming within the composition of cornu anterior, despite the conventionally accepted names, would appear to be problematical. In my opinion it is impossible to homologise the hypohyal built deep in between the basihyal and thyrohyal, not forming an independent mobile unit, in Cricetidae and Muridae, with the bone of the same name occurring in Soricidae, Talpa and Muscardinidae. In my opinion the hypohyal in Cricetidae and Muridae is an additional element, formation of which was caused by the action of muscular vectors. The angle formed between both bones was at first filled by a cartilage, and then later by a bone. Evidence of its more recent philogenetic origin is the fact of the later ossification in individual development of this element. The question of the occurrence of the hypohyal in Sciurus is left open in my work. It would seem that this bone does not occur in the squirrel. Tracing of the younger stages of development may supply an answer to this problem. Also the ceratohyal occurring in the Muridae and the Cricetidae examined would seem not to be a canonic element. This view is supported by the late ossification in individual development, or sometimes, such as in certain individuals of Mus, by behaviour in the cartilaginous stage. This element exhibits variation in shape and size, insertion in the muscles running to palatum molle. The bones coming within the composition of the cornua anteriores in the remaining mammals examined possess the characteristics of elements fulfilling analogical functions to those of the bony bridges, with their mobile connections, between the basihyal and skull.

\section{VI, CONCLUSIONS}

My own investigations and an analysis of relevant literature revealed:

1. Differences in the structure of different elements of the hyoid apparatus in both the orders of mammals examined, of all families and genera examined, and the occurrence of certain characteristic features only in individuals belonging to one species.

2. That the structure of the hyoid apparatus can be taken into consideration as one of the features of systematic importance. 
3. The shape, size and number of component units of the hyoid apparatus depend probably on the way in which sounds are uttered and the taking up of food, reduction to small particles and swallowing of same in different species.

4. The structure of the hyoid apparatus may be an indicator for future research on the utterance of sounds, connected with the problem of orientation in space and the instinct of self-preservation in small mammals.

\section{REFERENCES}

1. Cuvi e r, G., 1835: Leçons d'anatomie comparée. Paris, IV (acc. to S p r a g u e, 1943).

2. Dobs on, G. E., 1881: On the structure of pharynx, larynx and hyoid bones in the Epomophori. Proc. zool. Soc. Lond.: 685-693.

3. E1ias, H., 1907-1908: Zur Anatomie des Kehlkopfes des Microchiropteren. Morph. Jahrb., 37: 70-119.

4. (G a mbarya n, P. P. \& Dukielskaya, N. M.), Гамбарян, П. П. Дукельская Н. М., 1955: Крыса. Советская Наука: 1-254. Москва.

5. G a ughra n, G. R. L., 1954: A comparative study of the osteology and myology of the cranial and cervical regions of the shrew, Blarina brevicauda and the mole, Scalopus aquaticus. Univ. Mich. Misc. Publ., 80: 1-82. Ann. Arbor.

6. Kahmann, H. \& Ostermann, K., 1951: Wahrnemen und Hervorbringen höher Töne bei kleinen Säugetieren. Experientia, 7, 7: 241-280.

7. Möhres, F. P., 1952: Die Ultraschall Orientierung der Fledermäuse, Naturwissenschaften, $39,12: 273-279$.

8. Pierce, G. W. \& Griffin, D. R., 1938: J. Mammal, 19: 454 (acc. to Möhres, 1952).

9. Pockock, R. I., 1917: The classification of the existing Felidae. Ann. Mag. Nat. Hist. 20: $329-350$ (acc. to S p r a g u e, 1943).

10. S chleidt, W. M., 1948: Experientia 4:145 (acc. to Möh res, 1952).

11. Sprague, J. M., 1941: A study of the hyoid apparatus of the Cricetinae. J. Mamm., 22: 296-310.

12. Sprague, J. M., 1942: The hyoid apparatus of Neotoma. J. Mamm. 23: 405411.

13. Sprague, J. M., 1943: The hyoid region of placental mammals with especial reference to the bats. Am. J. Anat. 72: 385-472.

14. Sprague, J. M., 1944: The hyoid region in the Insectivora. Am. J. Anat., 74: $175-216$.

15. Tu 11 b e rg, T., 1899: Uber das System der Nagethiere. Soc. Upsala, Nova Acta Reg. Soc. Sci. Upsaliensis, 3, 18: 329-541 (acc. to Sprag u e, 1943).

Institute of Plant Protection,

Laboratory of the Study of Rodents, Poznań, Grunwaldzka 189. 


\section{STRESZCZENIE}

W literaturze polskiej brak jest opracowania dotyczącego aparatu gnykowego u występujących w kraju owadożernych i gryzoni. W literaturze światowej pierwsze opracowania odnoszące się do tematu podali Cuvier (1835), Tullberg (1899). Prace S prag u e $(1941 ; 1942 ; 1943 ; 1944)$ dają porównawezy przegląd budowy aparatu gnykowego u gryzoni, owadożernych i nietoperzy fauny Północno-Amerykańskiej.

W wyniku badań stwierdzono różnice w budowie poszczególnych elementów aparatu gnykowego u obu badanych rzędów ssaków polegające na sposobie wyksztalcenia poszczególnych elementów. Również poszczególne rodziny, rodzaje i gatunki mają aparat gnykowy wykształcony w charakterystyczny, im tylko właściwy sposób. Składowa ilość elementów aparatu gnykowego właściwa jest dla rodzaju. Największa ilość jednostek składowych występuje u Soricidae, Talpa, Nuscardinidae. U zwierząt tych kostny aparat gnykowy składa się z centralnie położonego basihyale, oraz 2 par rogów. W skład cornu anterior wchodzą: hypohyale, ceratohyale, stylohyale. Cornu posterior buduje thyrohyale. Różnice w ilości jednostek składowych aparatu gnykowego dotyczą cornu anterior. I tak u dorosłego osobnika Sciurus vulgaris róg przedni składa się $\mathrm{z}$ dwu członów: ceratohyale i stylohyale, $\mathrm{u}$ badanych przedstawicieli Microtidae i Muridae ruchomym członem rogu jest drobne, blaszkowate ceratohyale. Największe istotne różnice zachodzą w budowie basihyale. U Soricidae kość ta jest smukła, paliczkowata, u Talpa krótka, beleczkowata, nieckowato wgłębiona. U gryzoni belka kostna jest łukowato ugięta: u Cricetidae, Muridae, Sciurus w kierunku kranialnym, u Muscardinidae w kierunku wentralnym. Jeśli chodzi o wyksztalcenie krawędzi wentralnej kości, na której znajduje się u niektórych ssaków wyrostek językowy, jest ona gładka u Insectivora, Muscardinidae i Sciurus. Jeśli chodzi o Microtidae i Muridae budowa brzeżnej okolicy krawędzi wentralnej jest bardzo zróżnicowana. U Arvicola scherman, Microtus oeconomus tworzy strome trójkątne, u Micromys minutus, Rattus rattus, szeroko rozwarte trójkątne wzniesienie. Pojedyńczy wyrostek polożony przyśrodkowo występuje u Clethrionomys glareolus, Rattus rattus i czasem u Microtus arvalis oraz Arvicola terrestris, u których linia brzegowa tej krawędzi wykazuje zmienność. U wszystkich pozostałych gatunków z rodzaju Microtus, Apodemus, Mus musculus i Rattus norvegicus krawędź ta jest lukowato wysklepiona, silnie wywinięta w kierunku kranialnym u Mus musculus, słabiej u pozostałych gatunków, nieznacznie u Microtus sp. Również budowa thyrohyale wykazuje pewną zmienność u poszczególnych gatunków. Kość ta jest zawsze wydłużona, o grubszej nieco okolicy proksymalnej. U niektórych Muridae, Cricetidae i Talpa jest ona zwichrowana w długiej osi. U Sorex sp. i Dryomys kość ta jest paliczkowata, u Neomys bumerangowata, u Talpa i Glis dwubocznie spłaszczona. U Arvicola sp., Clethrionomys, Micromys, oraz u Sciurus kość ta jest maczugowata, ścieniająca się $\mathrm{W}$ miarę zbliżania do końca terminalnego. U Microtus sp., Apodemus sp., oraz Mus okolica terminalna kości jest poszerzona i zaokrąglona. Na końcu terminalnym thyrohyale u wszystkich badanych zwierząt znajduje się krótka, czapeczkowata chrzęstna nasadka za wyjątkiem rodzaju Sorex, a zwłaszcza Sorex caecutiens, u którego nasadka jest wydłużona, zachodzi łukiem na grzebietową stronę aparatu gnykowego, Również budowa, długość i ilość części składowych cornu anterior u poszczególnych gatunków nosi pewne cechy odrębności. Ciekawie przedstawia się również sprawa połączeń poszczególnych elementów składowych. U Insectivora wszystkie jednostki aparatu gnykowego połączone są ze 
sobą za pomocą stawów jamowych. U Rodentia thyrohyale połączone jest $\mathrm{z}$ basihyale za pomocą stawu pełnego. U Muscardinidae proksymalny człon cornu anterior - hypohyale lączy się z basihyale za pomocą stawu jamowego, natomiast u Muridae i Microtidae elementy te są połączone ze sobą stawem pełnym, staw jamowy występuje między trzonem kości gnykowej i ceratohyale. Podobnie przedstawia się połączenie ceratohyale u Sciurus, co do którego nie została wyjaśniona sprawa obecności hypohyale.

Zagadnienie homologii poszczególnych elementów szkieletu aparatu gnykowego w literaturze nie jest jasno sprecyzowane. Wydaje się, że u ssaków można mówić jedynie o basihyale jako pochodnej II luku trzewiowego i thyrohyale jako pochodnej III łuku trzewiowego. Człony natomiast cornu anterior wydają się być elementami niekanonicznymi, a nowopowstałymi, wywołanymi działaniem układów sił w tej okolicy ciała. Zazwyczaj cornu anterior biegnie od basihyale $\mathrm{w}$-kierunku bulla tympanica. U badanych Muridae i Microtidae, wbrew panującym w literaturze sądom, jest ono skierowane ku sklepieniu podniebienia.

Kształt, budowa, oraz ilość składowych elementów szkieletu aparatu gnykowego uzależnione są prawdopodobnie od sposobu wydawania dźwięków, pobierania, rozdrabniania i połykania pokarmu u poszczególnych gatunków.

Białostockie Zakłady Graficzne, Zam. 1572. Cena 6 zł.• F-2 